\title{
Investigation of Cyclohexanol as an Oxygenated Additive for Gasoline- Bioethanol Mixtures and Its Effect on the Combustion and Emission Characteristics of Spark Ignition Engines
}

\author{
Bambang Sugiarto ${ }^{*}$, Mohammad Fadhil Dwinanda1, Dika Auliady1, Rizeqi Nadhif Andito1, \\ Mokhtar $^{2}$, Chandra Simanjuntak ${ }^{1}$ \\ ${ }^{1}$ Department of Mechanical Engineering, Faculty of Engineering, Universitas Indonesia, Kampus UI Depok, \\ Depok 16424, Indonesia \\ ${ }^{2}$ Balai Teknologi Termodinamika Motor dan Propulsi, Badan Pengkajian dan Penerapan Teknologi (BPPT), \\ Kawasan Puspitek, Kota Tangerang Selatan 15314, Indonesia
}

\begin{abstract}
The quantity of internal combustion engine-powered motorized vehicles in Indonesia has been increasing year after year. As a result, fossil fuel demand has also increased beyond Indonesia's local production capacity, which decreases every year. The rapid growth of motorized vehicles also worsens air quality in Indonesia because of the combustion process in internal combustion engines, which produces toxic gases. One solution to this problem is to accelerate the usage of biofuels, in this context, bioethanol, as a fuel alternative. This study aims to determine the effect of oxygenated cyclohexanol additives to bioethanol-gasoline blends on 124.8 cc spark ignition (SI) engine performance and exhaust gas emission. The experiment was carried out using an engine dynamometer to measure engine performance, a pressure transducer to measure cylinder pressure, and a gas analyzer to measure exhaust gas emission. The experiment established that an $80 \%$ gasoline, 20\% bioethanol fuel mixture (E20 mixture) with the addition of $18 \mathrm{ml}$ of oxygenated cyclohexanol produced the best results among all the other mixtures tested; it lowered the specific fuel consumption (SFC) and coefficient of variation (COV) value, and produced fewer toxic gases, while minimizing power and torque losses.
\end{abstract}

Keywords: Bioethanol; Coefficient of variation; Gasoline; Oxygenated cyclohexanol; Spark ignition engine

\section{Introduction}

The number of vehicles in Indonesia increases every year. In 2019, the number of vehicles in Indonesia reached 133 million units (Gaikindo, 2021). The rapidly increasing number of vehicles has led directly to increased fuel consumption. Most of the energy consumed comes from fossil fuels, such as oil, natural gas, and coal. The consumption of fossil fuels in the transportation sector is said to have reached 64 million kiloliters in 2018. Meanwhile, national oil production has decreased almost every year since 2009 (SKK Migas, 2020). Because the use of fossil fuels is directly related to the increase in the number of vehicles, air quality is also destined to get worse due to the increased number of vehicles because the products of combustion in vehicle engines increase the concentration of toxic

${ }^{*}$ Corresponding author's email: bangsugi@yahoo.com, Tel.: +62-811-860153

doi: 10.14716/ijtech.v12i5.5204 
gases such as carbon monoxide (CO), hydrocarbons (HC), and sulphur oxide (SOx) in the air. Of the most polluted countries in 2020 (IQAir, 2020), Indonesia was ranked $9^{\text {th }}$ with an index of PM2.5, air particles that are smaller than $2.5 \mu \mathrm{m}$, reaching $40.7 \mu \mathrm{g} / \mathrm{m}^{3}$. This was four times higher than the limit recommended by the WHO, $10 \mu \mathrm{g} / \mathrm{m}^{3}$. Hence, according to the US air quality index (AQI), Indonesia's air was defined as unhealthy for the community.

To maintain the level of energy supply stability in Indonesia and also to reduce fuel emissions, alternative energy sources were required. In recent years, ethanol-based fuels have been favored because their physical properties and characteristics share many similarities with gasoline. Bioethanol is produced from biomass (Hossain et al., 2017) and provides a range of benefits, such as its ability to be mixed with gasoline to increase a fuel's RON rating. The characteristics of gasoline-ethanol blends include density that increases linearly and a research octane number (RON) that increases with the blend's percentage volume of ethanol (Wibowo et al., 2020). Bioethanol $\left(\mathrm{C}_{2} \mathrm{H}_{5} \mathrm{OH}\right)$ is derived from plants that contain starch. The drawbacks of bioethanol are a lower energy density than gasoline (bioethanol has $66 \%$ of the energy that gasoline has), its corrosive properties, low flame luminosity, lower vapor pressure (making cold starts difficult), miscibility with water, and toxicity and adverse effects in biological systems (Majid et al., 2016). On top of that, the mixing of gasoline and bioethanol is far from perfect due to the difference in the polar and non-polar properties of the mixture, which causes the mixture to tend to be separated into phases and become inhomogeneous (Srinivasan and Saravanan, 2010). Therefore, an additive is required so that the two fuels can mix together to become homogeneous.

There are several classifications of additives according to their purposes. Antioxidantcosolvent additives are suitable for increasing phase stability (Srivastava and Hancsok, 2014). There are three types of cosolvents that are common in use: branched higher alcohols, higher aliphatic alcohols, and ethers (Honig et al., 2015). Cyclohexanol is a higher aliphatic alcohol, which are also categorized as secondary alcohols with ring-shaped chains. As a secondary alcohol, cyclohexanol is more stable and reactive than primary alcohols (methanol, ethanol).

An investigation done by Amine and Barakat (2021) on a 95\% gasoline, $5 \%$ bioethanol fuel mixture (E5) and a 90\% gasoline, 10\% bioethanol fuel mixture (E10) determined that phase separation occurred at $30^{\circ} \mathrm{C}$. Meanwhile after the addition of cyclohexanol to the fuel mixture, the phase became more stable and no phase separation occurred. Also, with a higher percentage of bioethanol, the addition of cyclohexanol would further improve water tolerance to $1.4 \% \mathrm{v} / \mathrm{v}$ for E20.

Waluyo et al. (2020) studied the role of cosolvent in an isooctane-methanol blend. Assessed visually, the isooctane-methanol fuel blend separated into several parts at room temperature. Then, after the addition of cosolvent, no separation occurred. According to molecular modeling using semi-empirical quantum mechanics provided by HyperChem software, the addition of cosolvent into the isooctane-methanol blend improved molecular interactions among its constituents, making the fuel mixture more homogeneous and stable.

Srinivasan and Saravanan (2010) conducted an experiment using a gasolinebioethanol mixture with an oxygenated additive on a three-cylinder, $796 \mathrm{cc}$, four-stroke, SI engine. The combustion process occurred while the maximum load was maintained at $40 \mathrm{~N}$ - 3000 rpm. Exhaust gas emission, engine performance, brake thermal efficiency, and heat release parameters were obtained from the experiment. It was found that there was a slight reduction in the exhaust emission content of $\mathrm{CO}, \mathrm{CO}_{2}$, and $\mathrm{NO}_{x}$, but that $\mathrm{HC}$ and $\mathrm{O}_{2}$ moderately increased. Also, engine power and torque were enhanced compared to fuel alone.

Abikusna et al. (2020) explained the variations in combustion in each engine cycle. The maximum cylinder pressure and the crank angle position when maximum pressure occurs is different for every cycle. A statistical method was used to represent the ratio of standard 
deviation to the mean of a set of data, also called the coefficient of variation (COV). It provided evidence that the addition of an oxygenated additive into the fuel mixture led to a decrease in combustion variation, lowering the COV.

This experiment aimed to understand the character of gasoline-bioethanol mixtures with cyclohexanol as an oxygenated additive. Previous research had established that the addition of cyclohexanol as an oxygenated additive to a gasoline-bioethanol mixture would reduce the exhaust emission content of $\mathrm{CO}, \mathrm{CO}_{2}$, and $\mathrm{NO}_{\mathrm{x}}$. In this research, the gasolinebioethanol mixture was set to a ratio that was more applicable to unmodified engines. The bioethanol percentage was set to no more than $20 \%$ of the mixture's total volume. The percentage of cyclohexanol in the mixture was also increased from previous studies to find out if the increase would improve combustion. The experiment was conducted locally with an unmodified SI engine as the experimental object. The COV, engine power, torque, and exhaust emission produced by the engine were also investigated.

\section{Methods}

\subsection{Equation}

In this experiment, the COV, engine power, torque, specific fuel consumption (SFC), and exhaust emission were calculated, recorded, and analyzed to further investigate the effects of a cyclohexanol additive to a gasoline-bioethanol fuel mixture on its combustion and emission characteristics in a spark ignition (SI) engine.

In this section, the COV, engine power, torque, and SFC equations that were used to calculate the data are explained. For the exhaust emission, the data was recorded using a gas analyzer.

Equation 1 explains how to calculate the COV value from each combustion cycle:

$$
\operatorname{COV}=\frac{\sigma I M E P}{\mu I M E P} \times 100
$$

where $\sigma I M E P$ is the standard deviation of combustion pressure per cycle, and $\mu I M E P$ is average pressure per cycle. Equation 2 explains how to calculate torque using an engine dynamometer:

$$
T=F \cdot L
$$

where $F$ is the balance reading added weight stated in Newtons, and $L$ is the torque arm length stated in meters. Equation 3 explains how to calculate engine power from the torque value calculated in Equation 2:

$$
P e=\frac{2 . \pi \cdot n}{60} T
$$

where Pe stands for power generated by the engine, stated in Watts, $n$ is engine rounds per minute (rpm), and $T$ stands for torque, as in Equation 2. Equation 4 shows how to calculate the $S F C$ using the engine power value calculated in Equation 3:

$$
S F C=\frac{m_{f} \times 10^{3}}{P e}
$$

Specific fuel consumption is the amount of mass rate flow of a fuel needed to produce each power output unit (Wibowo et al., 2020). SFC is expressed as $\mathrm{g} / \mathrm{kWh} ; m f$ stands for fuel mass flow rate, stated in $\mathrm{kg} / \mathrm{s}$, and $P e$ is the power generated by the engine, as in Equation 3.

\subsection{Experimental Setup}

Gasoline RON 88 was used as the sole fuel (henceforth referred to as E0). It was then mixed with bioethanol to form an $85 \%$ gasoline, $15 \%$ bioethanol fuel mixture (E15) and an 

and Its Effect on the Combustion and Emission Characteristics of Spark Ignition Engines

$80 \%$ gasoline, 20\% bioethanol fuel mixture (E20). Furthermore, 5, 13, and $18 \mathrm{mls}$ of cyclohexanol $\left(\mathrm{CH}_{\mathrm{x}}\right)$ were added to the fuel mixture to form combinations of gasolinebioethanol-oxygenated additive, the compositions of which can be seen in Table 1.

Table 1 Fuel blend compositions

\begin{tabular}{cccc}
\hline Fuel Mixture & Gasoline (\%) & $\begin{array}{c}\text { Bioethanol } \\
(\%)\end{array}$ & $\begin{array}{c}\text { Cyclohexanol } \\
(\mathrm{ml})\end{array}$ \\
\hline E0 & 100 & 0 & 0 \\
$\mathrm{E} 15$ & 85 & 15 & 0 \\
$\mathrm{E} 15+5 \mathrm{ml} \mathrm{CH} \mathrm{x}_{\mathrm{x}}$ & 85 & 15 & 5 \\
$\mathrm{E} 15+13 \mathrm{ml} \mathrm{CH}$ & 85 & 15 & 13 \\
$\mathrm{E} 15+18 \mathrm{ml} \mathrm{CH}$ & 85 & 15 & 18 \\
$\mathrm{E} 20$ & 80 & 20 & 0 \\
$\mathrm{E} 20+5 \mathrm{ml} \mathrm{CH}$ & 80 & 20 & 5 \\
$\mathrm{E} 20+13 \mathrm{ml} \mathrm{CH}_{\mathrm{x}}$ & 80 & 20 & 13 \\
E20+18 ml CH & 80 & 20 & 18 \\
\hline
\end{tabular}

The experiment was conducted at Balai Teknologi Termodinamika Motor dan PropulsiBadan Pengkajian dan Penerapan Teknologi (BT2MP-BPPT). The engine specifications used for this experiment are given in Table 2, and the experimental set up is shown in Figure 1.

Table 2 Engine specification

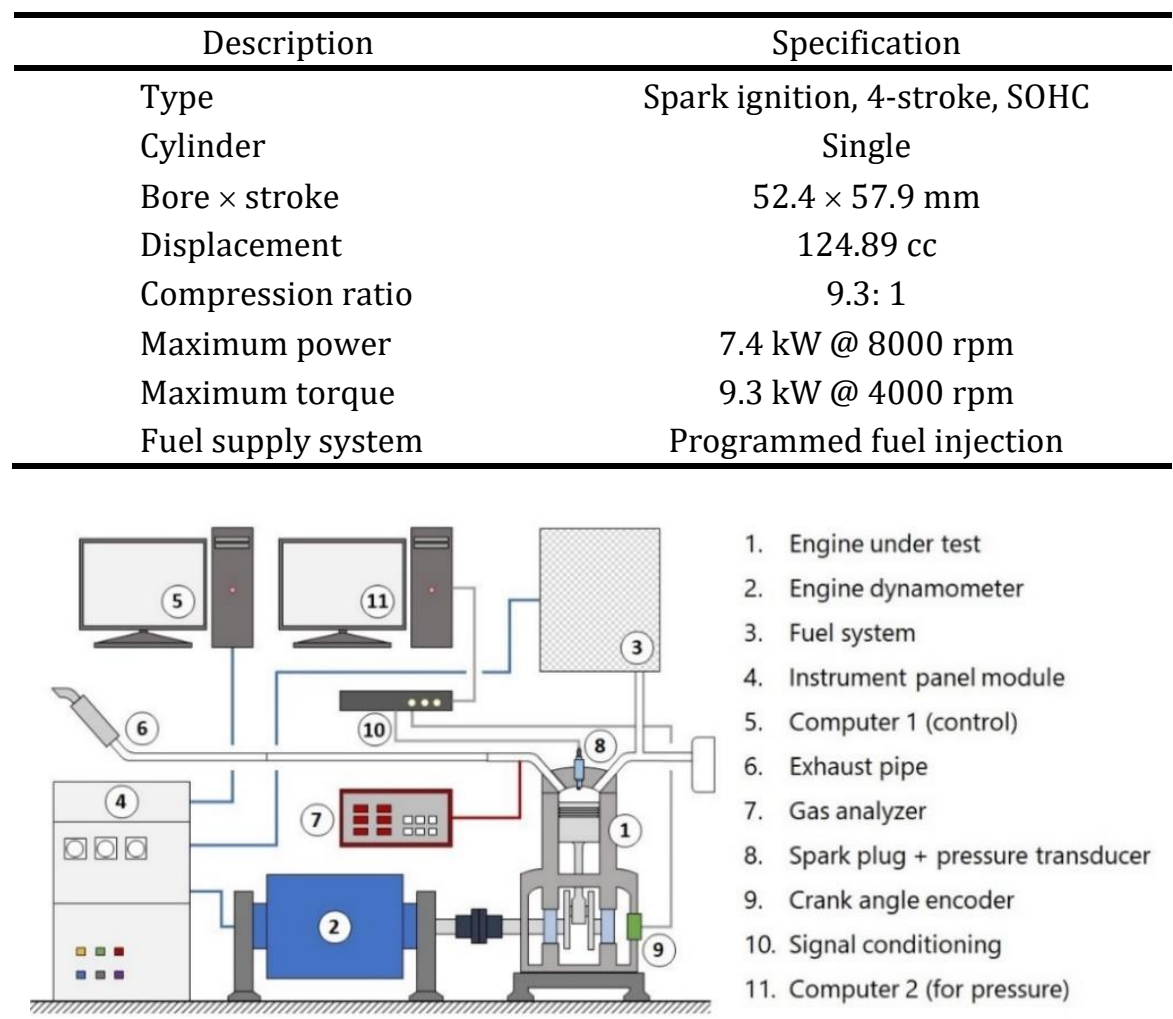

Figure 1 Experimental set-up

The engine (Honda SI Engine 125 CC, Tokyo, Japan) was connected to an engine dynamometer for load measurement. The engine dynamometer was then connected to a computer for controlling and recording purposes; the instrument panel served as a data and signal processing device. Fuel systems were also connected to the same computer 
through these instrument panels. The amount of carbon monoxide ( $\mathrm{CO}$ ), carbon dioxide $\left(\mathrm{CO}_{2}\right)$, oxygen $\left(\mathrm{O}_{2}\right)$, and hydrocarbon $(\mathrm{HC})$ from the exhaust pipe was measured by using the gas analyzer QROTECH-402 (Bucheon, South Korea). To measure the cylinder pressure, a Kistler 6117B piezoelectric pressure transducer (Winterthur, Switzerland) was installed at the spark plug hole. A crank angle encoder was connected to a second computer for setting and recording purposes, using a National Instrument SC-234 signal conditioning device (Tokyo, Japan). The engine ran with the throttle open $100 \%$ for $4000 \mathrm{rpm}, 6000 \mathrm{rpm}$, and $8500 \mathrm{rpm}$ at a $100 \%$ load.

The engine was allowed to run with an E0 mixture at a speed of 4000-8500 rpm in 500 rpm increments. At each engine speed, the throttle valve was opened $100 \%$. Data on power, torque, SFC, the COV, and exhaust emissions were obtained for each engine speed. After finishing the experiment with E0, the experiment was then conducted with other fuel mixtures. All fuel blends were examined using the same procedure. The effects of a cyclohexanol additive on spark ignition engine performance were investigated.

\section{Results and Discussion}

\subsection{Coefficient of Variation}

The effect of a gasoline-ethanol with cyclohexanol blend on the COV is shown in Figure 2. Low, intermediate, and high engine speeds of $4000 \mathrm{rpm}, 6000 \mathrm{rpm}$, and $8500 \mathrm{rpm}$ were investigated. The lowest COV, 2.46\%, was obtained using E20 + $18 \mathrm{ml}$ cyclohexanol, while for just E20, the lowest COV was $6.21 \%$. The addition of cyclohexanol into the fuel mixture further improved the COV compared to the gasoline-bioethanol mixture alone. This might indicate that the presence of cyclohexanol as an antioxidant - cosolvent additive improved the fuel mixture's homogeneity. This is according to Honig et al., (2015) who said, "Cyclohexanol is considered a higher aliphatic alcohol and can also be categorized as a secondary alcohol with a ring-shaped chain. As a secondary alcohol, cyclohexanol is more stable and reactive than primary alcohol (methanol, ethanol)."

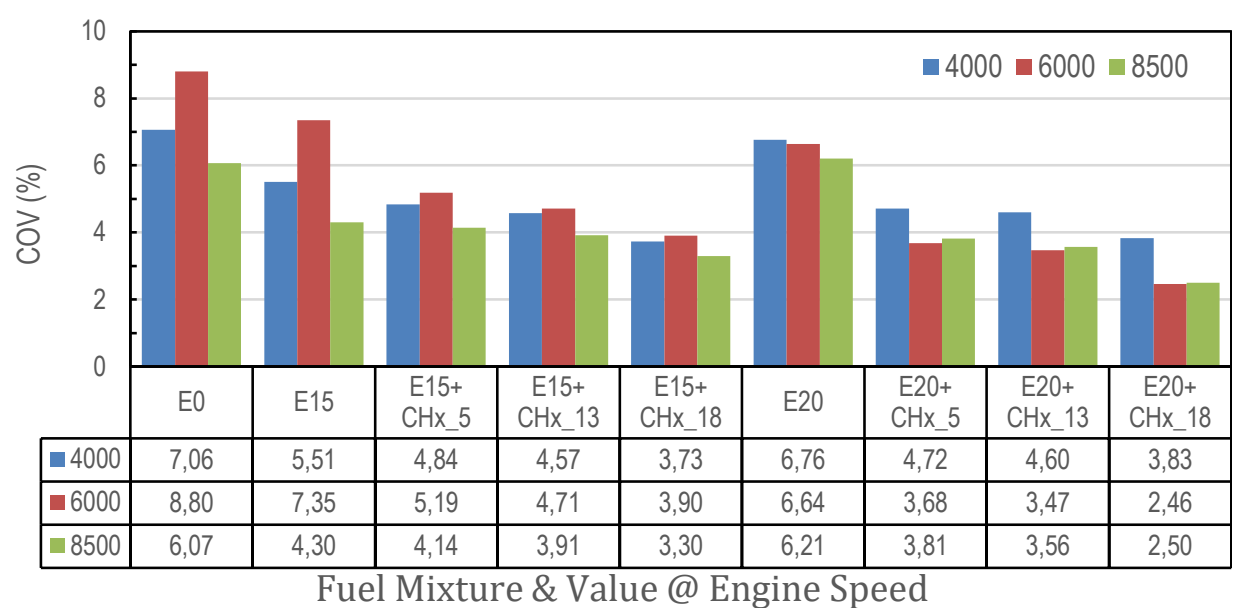

Figure 2 COV vs. Engine speed

\subsection{Power}

Figure 3a shows the results of power testing on a test engine with an engine speed of 4000-8500 rpm, increasing in $500 \mathrm{rpm}$ intervals, for all fuel variations. The experiment was done 20 times and produced 20 specimens; from there, the specimens were averaged to be represented as a single value in the graph. It is clear from the graph that each fuel has almost the same trendline. E0 has the highest maximum power at $6.30 \mathrm{~kW}$, while E20 + 18 $\mathrm{ml}$ cyclohexanol has the lowest maximum power at $5.86 \mathrm{~kW}$. It can also be seen that the 
power generated by each fuel variable at an engine speed of $4000-8500 \mathrm{rpm}$ is not constant; this is due to cycle-to-cycle variations in the combustion process that can be caused by the temperature in the combustion chamber, the ignition process, and other factors.

In addition, it is evident that the addition of ethanol and cyclohexanol additives at certain concentrations actually caused a decrease in power in the test machine. However, the decrease that occurred was arguably not very significant, so it can be said that the power produced by the fuel mixed with ethanol and cyclohexanol additives was almost the same as the power produced by RON 88.

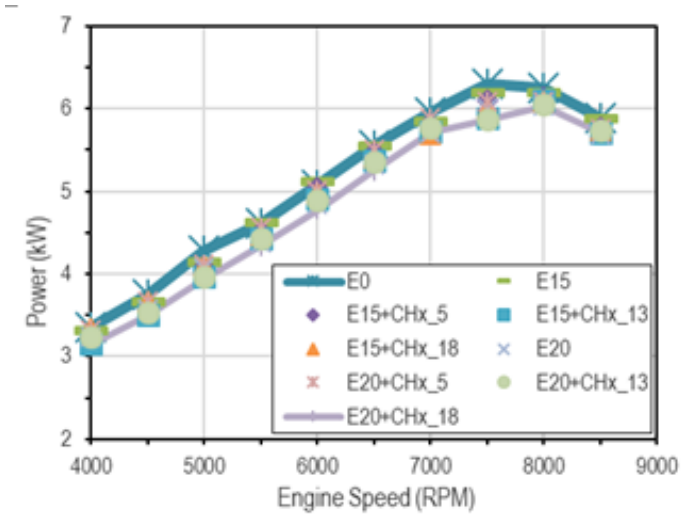

(a)

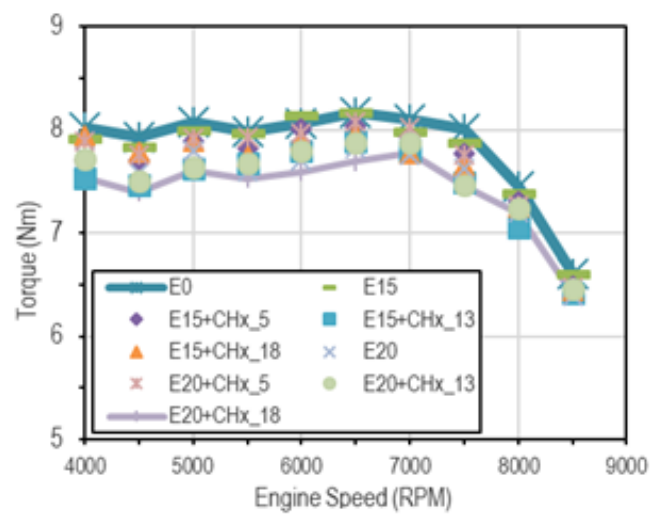

(b)

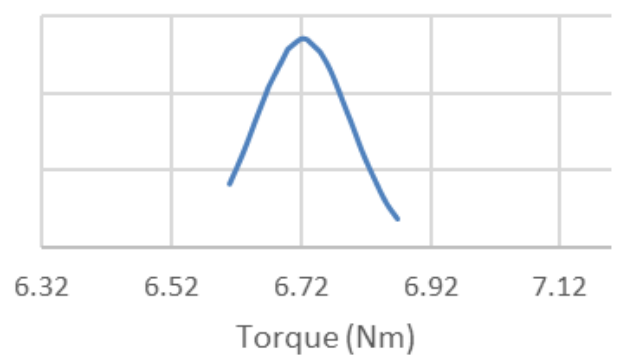

(c)

Figure 3 Performance results: (a) Power vs. Engine speed all mixtures; (b) Torque vs. Engine speed all mixtures; and (c) Standard deviation graph example on torque @E0, 8500 rpm

\subsection{Torque}

In Figure 3b, it can be seen that the peak torque for each fuel variable occurred at around $4000 \mathrm{rpm}$. The highest maximum torque was produced by E0 with $8.09 \mathrm{Nm}$, and the lowest maximum torque was produced by E20 + $18 \mathrm{ml}$ cyclohexanol with $7.6 \mathrm{Nm}$. This occurred because at that point in the rotation, the engine produces a maximum torque to move the vehicle. In addition, at this relatively low speed, the losses that occur in the combustion process are still small, so the volumetric efficiency of the engine is still high. Meanwhile, the losses will increase as the engine speed gets higher. This caused by friction between engine components, losses in the inlet, and exhaust valve settings at higher engine speed. Also, the valve control does not have enough time to let fresh air enter into the engine, so the pressure decreases.

It can also be seen that with increasing amounts of ethanol and cyclohexanol in the RON 88, the torque produced decreased by small amounts due to the lower calorific value of the fuel compared to E0 (Maárof et al., 2020). The torque generated at engine speeds of 4000$8500 \mathrm{rpm}$ for each fuel variable is inconsistent due to cycle variations that occur in the combustion process caused by several parameters, such as the geometry of the combustion chamber, the fuel mixture, and others. 


\subsection{Specific Fuel Consumption}

As shown in Figure 4, E0, the pure gasoline mixture, produced the lowest SFC value when compared with E15 and E15 with additives. This happened because the density of bioethanol $(0.79 \mathrm{~kg} / \mathrm{L})$ is higher than pure gasoline $(0.7-0.75 \mathrm{~kg} / \mathrm{L})$. So, at the same volume, bioethanol is heavier than gasoline. Thus, the greater the percentage of bioethanol in the fuel mixture, the higher the SFC value will be. Additionally, the calorific value of bioethanol $(26.700 \mathrm{~kJ} / \mathrm{kg})$ is only about $63 \%$ of the calorific value of pure gasoline $(42.600 \mathrm{~kJ} / \mathrm{kg})$, which means more fuel mixture is required to produce the same energy (Srinivasan and Saravanan, 2010).

It is also evident that as the oxygenated cyclohexanol volume increases in the E15 + 18 $\mathrm{ml}$ mixture, the SFC value of the fuel mixtures will decrease and approach the SFC value of E0. Even though the SFC value of E0 is still the lowest, Figure 4a demonstrates that as the volume of oxygenated cyclohexanol in fuel mixtures increases, the SFC value of the E15 mixture will continue to decrease and approach the SFC value of E0.

The trend shown in Figure $4 \mathrm{a}$ can be seen again in Figure $4 \mathrm{~b}$. Pure gasoline, E0, produced the lowest SFC value when compared to E20 and E20 with additives. The SFC value of E20 without additives is the highest among all mixtures in Figure 6. As the volume of oxygenated cyclohexanol in fuel mixtures increases, the SFC value will decrease and approach the SFC value of E0. E20 $+18 \mathrm{ml}$ additive is the mixture that has the closest SFC value to E0. From Figure 4, it can be concluded that as the volume of oxygenated cyclohexanol in the fuel mixtures increases, the SFC value will decrease, thus improving the fuel efficiency of the test engine.

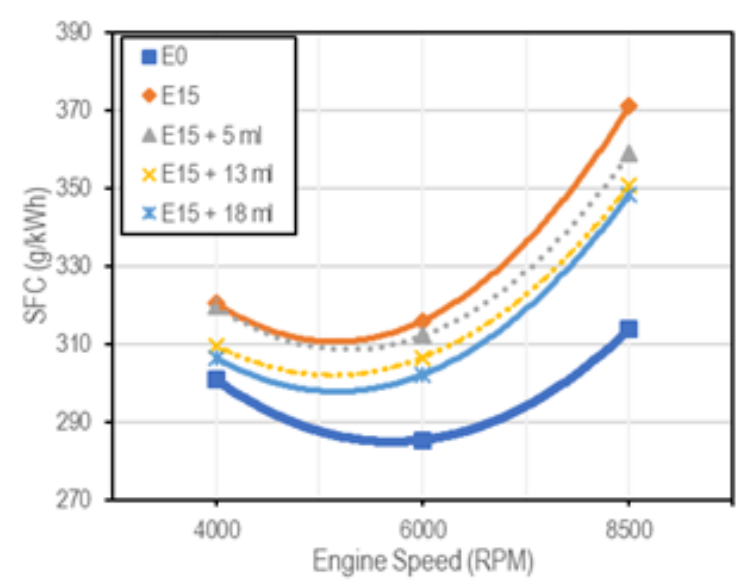

(a)

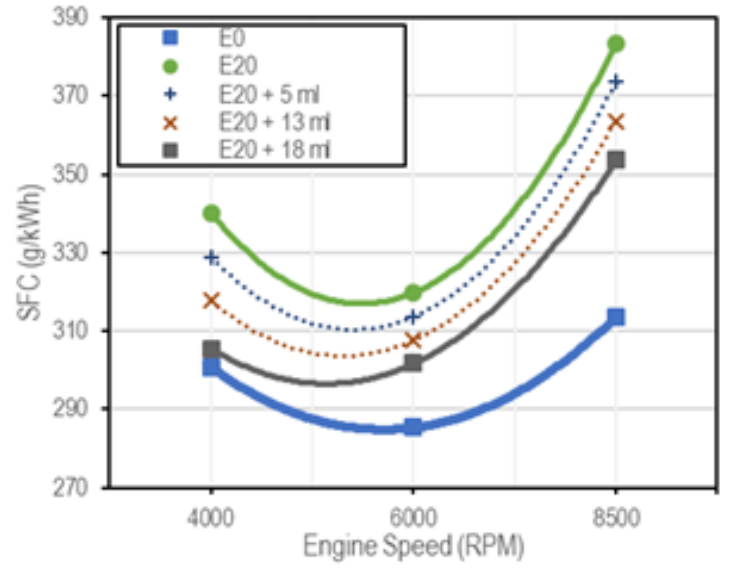

(b)

Figure 4 Performance result: (a) SFC vs. Engine speed, E15 \& E15 + additives; and (b) SFC vs. Engine speed, E20 \& E20 + additives

\subsection{CO Emissions}

The effect of the bioethanol and oxygenated additives cyclohexanol mixtures on CO emission is shown in Figure 5a. As engine speed was increased, the CO produced from combustion also increased. The lowest CO content was $0.1 \%$, generated with the use of bioethanol E20 with cyclohexanol $18 \mathrm{ml}$ at $4000 \mathrm{rpm}$. The highest producer of CO was gasoline at $8000 \mathrm{rpm}$, with $1.7 \%$. The high amount of $\mathrm{CO}$ was caused by the lack of oxygen during combustion. During combustion, hydrocarbon should be reacting with oxygen and producing $\mathrm{CO}_{2}$. The use of bioethanol made the $\mathrm{CO}$ content in the emissions less than that produced by gasoline because bioethanol contains more oxygen and causes more HC to react (Sugiarto et al., 2021). Furthermore, the use of cyclohexanol, which has more oxygen, 

and Its Effect on the Combustion and Emission Characteristics of Spark Ignition Engines

caused all of the HC to react and completely burn. The air-fuel ratios for all conditions were around 14.7:1. According to the stoichiometry air-fuel ratios, there was no excess oxygen from outside that contributed to combustion (Sugiarto, 2005).

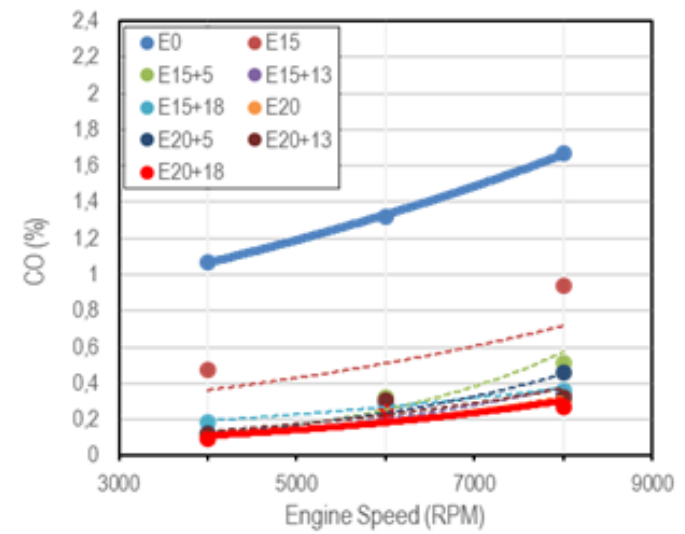

(a)

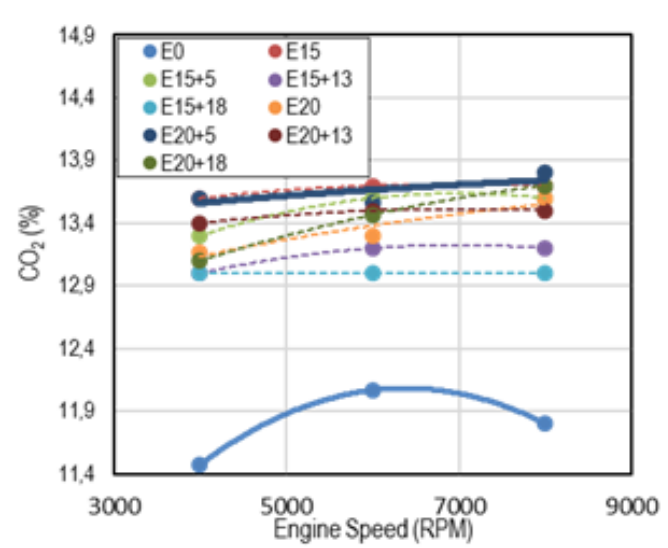

(b)

Figure 5 Performance result: (a) $\mathrm{CO}$ emission vs. Engine speed; and (b) $\mathrm{CO}_{2}$ emission vs. Engine speed

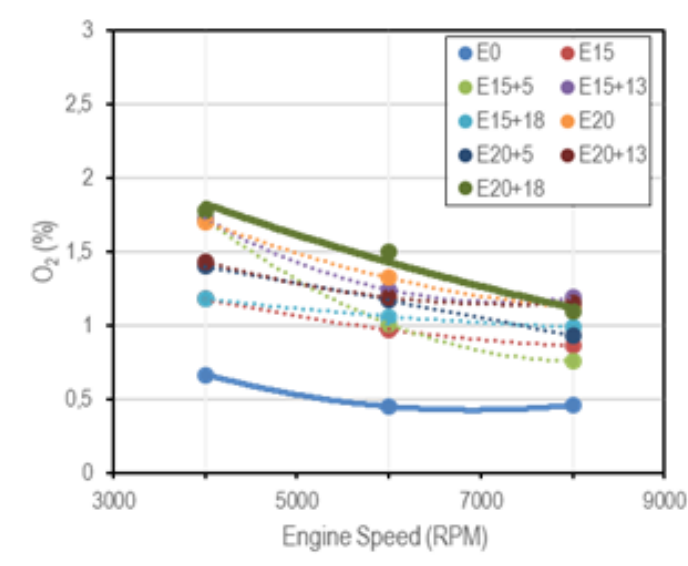

(a)

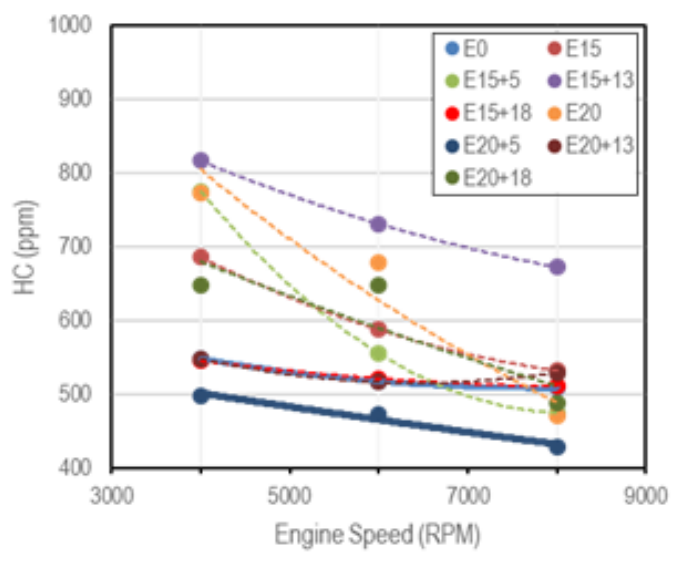

(b)

Figure 6 Performance results: (a) $\mathrm{O}_{2}$ emission vs. Engine speed; and (b) HC emission vs. Engine speed

\section{6. $\mathrm{CO}_{2}$ Emissions}

The effect of bioethanol with oxygenated additives on the emission of $\mathrm{CO}_{2}$ is shown in Figure $5 \mathrm{~b}$. As the engine speed was increased, the combustion process tended to produce more $\mathrm{CO}_{2}$ emissions. Increased volumes of bioethanol and cyclohexanol substances were proven to generate higher $\mathrm{CO}_{2}$ emissions. Compared to gasoline, the highest improvement was generated by bioethanol $20 \%$ and cyclohexanol, with a value of $13.8 \%$. The baseline, gasoline, produced less $\mathrm{CO}_{2}$, which was a sign of incomplete combustion. The bioethanol with additives contained higher levels of oxygen molecules $(-\mathrm{OH})$, which is why when combustion occurred, the carbon molecules bound with more oxygen molecules to produce $\mathrm{CO}_{2}$ rather than $\mathrm{CO}$ (Abikusna et al., 2020).

\section{7. $\mathrm{O}_{2}$ Emissions}

The effect of the bioethanol and cyclohexanol blends on the emission of $\mathrm{O}_{2}$ is shown in Figure 6a. At every range of speed, $\mathrm{O}_{2}$ emissions were found to occur at a higher percentage with the addition of bioethanol and cyclohexanol. Gasoline had a better level of $\mathrm{O}_{2}$ emission than fuel with bioethanol and cyclohexanol. The highest percentage of $\mathrm{O}_{2}$ emissions 
generated at the lowest speed of $4000 \mathrm{rpm}$ was $1.8 \%$ for the mixture of E20 with $18 \mathrm{ml}$ of cyclohexanol. As previously stated, this might be because the oxygen content in ethanol and cyclohexanol is high enough that there is a lot of oxygen that is not burned in the exhaust gas.

\subsection{HC Emissions}

Figure $6 \mathrm{~b}$ shows that the HC produced by E20 with $5 \mathrm{ml}$ of cyclohexanol is the lowest among the other types of fuel, with $425 \mathrm{ppm}$ at $8000 \mathrm{rpm}$, while the HC content of the exhaust gas for gasoline was higher at $500 \mathrm{ppm}$ at $8000 \mathrm{rpm}$. The addition of cyclohexanol additives is the same as adding oxygen to the mixture to help combustion break down the carbon chains of gasoline so that less gasoline is wasted. Ethanol is proven to reduce the amount of HC in the exhaust gas from pure gasoline. Unburned HC can be caused by many factors, including the temperature in the combustion chamber (Sugiarto et al., 2021). The unburned layer on the surface of the combustion chamber wall with gasoline-bioethanol mixture is thinner than with pure gasoline (Srinivasan and Saravanan, 2010). This is so that the fire can spread more and reduce HCs. But to change the phase of bioethanol is more difficult because it requires more energy than ordinary gasoline (Tornatore et al., 2019). In addition, by increasing the engine rotation speed, the amount of HC from each gasolinebioethanol mixture decreases because the valve opens and closes and ignition timing becomes more precise, making combustion more complete.

\section{Conclusions}

Based on the experiment conducted on the $124.8 \mathrm{cc}$ unmodified SI engine, it can be concluded that the addition of oxygenated additives to cyclohexanol improves the COV. Higher percentages of bioethanol with the addition of cyclohexanol would produce better COVs. The power and torque generated were reduced, though not significantly, due to the lower energy contained in bioethanol compared to gasoline. There was an improvement in SFC with the addition of cyclohexanol compared to the gasoline-bioethanol mixture alone. But in general, the value of SFC with bioethanol was higher than with E0 because of the higher density of bioethanol compared to gasoline. The exhaust emissions produced by the engine also improved with the addition of cyclohexanol, but primarily the improvements were influenced by the percentage of bioethanol in the fuel mixture.

\section{Acknowledgements}

The authors would like to acknowledge Universitas Indonesia for funding this research through the contract PUTI No. NKB-1116/UN2.RST/HKP.05.00/2020, and Balai Teknologi Termodinamika Motor dan Propulsi - Badan Pengkajian dan Penerapan Teknologi (BT2MPBPPT) for providing space, laboratory facilities, and knowledge. The authors greatly appreciate the support.

\section{References}

Abikusna, S., Sugiarto, B., Yamin, I., 2020. Utilization Analysis of Bioethanol (Low Grade) and Oxygenated Additive to COV and Gas Emissions on SI Engine. Evergreen, Volume 7(1), pp. 43-50

Amine, M., Barakat, Y., 2021. Effect of Cyclohexanol on Phase Stability and Volatility Behaviour of Hydrous Ethanol-Gasoline Blends. Egyptian Journal of Petroleum, Volume 30(3), pp. 7-12

Gabungan Industri Kendaraan Bermotor Indonesia (Gaikindo), 2021. Hasil Sensus BPS: Jumlah Kendaraan Bermotor di Indonesia Tembus 133 Juta Unit (BPS Census Results: 

and Its Effect on the Combustion and Emission Characteristics of Spark Ignition Engines

Number of Motorized Vehicles in Indonesia Reaches 133 Million Units). Available Online at https://www.gaikindo.or.id/data-bps-jumlah-kendaraan-bermotor-di-indonesiatembus-133-juta-unit/, Accessed on May 27, 2021

Honig, V., Linhart, Z., Taborsky, J., Marik, J., 2015. Determination of the Phase Separation Temperature and the Water Solubility in the Mixtures of Gasoline with Biobutanol and Bioethanol. Agronomy Research, Volume 13(2), pp. 550-557

Hossain, N., Zaini, J.H., Mahlia, T., 2017. A Review of Bioethanol Production from Plant-based Waste Biomass by Yeast Fermentation. International Journal of Technology, Volume 8(1), pp. 5-18

IQAir, 2020. Air Quality in Indonesia. Available Online at https://www.iqair.com/indonesia, Accessed on May 27, 2021

Maárof, M., Chala, G., Gunness, D., Saad, I., 2020. A Study on the Performance Analysis of Bioethanol Produced from Sugarcane Molasses in SI Engine. In: IOP Conference Series: Materials Science and Engineering, Volume 863, pp. 1-10

Majid, Z.A., Mohsin, R., Nasri, N.S., 2016. Effect of Bioethanol on Engine Performance and Exhaust Emissions of a Diesel Fuel Engine. International Journal of Technology, Volume 7(6), pp. 972-980

Satuan Kerja Khusus Pelaksana Kegiatan Usaha Hulu Minyak dan Gas Bumi (SKK Migas), 2020. Laporan Tahunan 2019 (Annual Report 2019). Available Online at www.skkmigas.go.id/assets/ar-skk-migas-2019-indo-rev-170702020.pdf, Accessed on May 5, 2021

Srinivasan, C.A., Saravanan, C.G., 2010. Study of Combustion Characteristics of an SI Engine Fuelled with Ethanol and Oxygenated Fuel Additives. Journal of Sustainable Energy and Environment, Volume 1, pp. 85-91

Srivastava, S.P., Hancsok, J., 2014. Fuels and Fuel Additives. John Wiley \& Sons Inc., Hoboken, New Jersey, USA

Sugiarto, B., 2005. Motor Pembakaran Dalam (Internal Combustion Engine). Universitas Indonesia, Jakarta, Indonesia, ISBN 979-97726-7-2

Sugiarto, B., Adrian, A.P., Simanjuntak, C., Nubli, N.A., Farisa, N., 2021. The Effect of LowGrade Bioethanol and Oxygenated Cyclooctanol Additive Utilization on a 125 cc Motor's Exhaust Gas Emission and Coefficient of Variation. In: AIP Conference Proceedings, Volume 2376(1), https://doi.org/10.1063/5.0064286

Tornatore, C., Marchitto, L., Costagliola, M.A., Valentino, G., 2019. Experimental Comparative Study on Performance and Emissions of E85 Adopting Different Injection Approaches in a Turbocharged PFI SI Engine. Energies, Volume 12(8), pp. 1-15

Waluyo, B., Setiyo, M., Saifudin, Wardana, I.N.G., 2020. The Role of Ethanol as a Cosolvent for Isooctane-Methanol Blend. Fuel, Volume 262, https://doi.org/10.1016/j.fuel.2019.116465

Wibowo, C.S., Setiady, N.I., Masuku, M., Hamzah, A., Fedori, I., Maymuchar, Nugroho, Y.S., Sugiarto, B., 2020. The Performance of a Spark Ignition Engine using 92 RON Gasoline with Varying Blends of Bioethanol (E40, E50, E60) Measured using a Dynamometer Test. International Journal of Technology. Volume 11(7), pp. 1380-1387 